\title{
Study on the Present Situation and Risk Pre-warning Mechanism of Local Debt in China
}

\author{
Lingyan $\mathrm{Ou}^{1,2, a}$, Yan $\operatorname{Pan}^{1,3, b}$ \\ ${ }^{1}$ Financial and Accounting Research Center, Social science research base of Fujian Province, \\ Fuzhou 350000, China \\ ${ }^{2}$ Department of Accounting, Fujian Jiangxia University, Fuzhou 350000, China \\ ${ }^{3}$ School of economics and management, Fuzhou University, Fuzhou 350000, China \\ a22087335@qq.com, bfzdxpy@163.com
}

Keywords: Local Debt, Risk, Pre-warning Mechanism.

\begin{abstract}
In recent years, the scale and quantity of China's local debts have been changing constantly, and the problem of local debt risk has become one of the focus attention of the government and all circles of society. This paper analyzes the relevant concepts of local debt, expounds the current situation of local debt, and briefly analyzes its potential risks, then puts forward how to build a risk prevention and pre-warning mechanism. The aim is to provide suggestions for the management of the local government debt risk and for ensuring the steady growth of China's economy.
\end{abstract}

\section{Introduction}

For a long time, in order to further expand the local economy, the local government has borrowed heavily from the local financing platform, then cause the local debt has been expanding rapidly. According to prediction, the first half of 2017, China will face the peak of debt repayment, long-term accumulation of local government debt risk and potential risk has been one of the priority problems to prevent the economic operation.

Now the Chinese government has also implemented a series of countermeasures against the potential risk caused by local debts. Since 2014, government has promulgated the "opinions" on the strengthening of local government debt management and basically built a system framework of local debt management. The acts contains: the implementation of quota management of local debt, a series of reform measures of local debt under budgetary management, the strengthening of local government debt risk pre-warning and monitoring, etc. However, in the process of actual implementation, how to solve the corresponding risk problems still have a long way to go. By analyzing the present situation of the local government debt in China, this paper analyzes the existing problems from the angle of risk and puts forward the corresponding countermeasures, aiming at providing countermeasures for the management of the local government debt risk.

\section{The Concept Explanation of Local Government Debt}

\subsection{Local Debt}

Local debt can be divided into two types: explicit debt and implicit debt. Explicit debt generally include foreign governments and international financial organizations loans, bond lending funds, comprehensive agricultural development loans, special loans to local financial risks, solve the arrears of wages of state-owned grain enterprises, the loss of old and new credit, arrears of basic old-age pensions for retirees from enterprises, in addition to explicit liabilities usually unpaid expenses payable.

The implicit debt including local government guaranteed debt, secured debt, local financial institutions bad debts, the social security fund gap, in financial institutions liquidation when local governments will bear the loss of assets. These debts has become the main danger zone of Chinese local debt risk due to the lack of effective monitoring and unified management system. 


\subsection{Local Debt Risk}

The so-called local debt risk, refers to possibility of the local financial funds suffered losses or financial difficulties, thus endangering the normal function of the local government. Local debt risk has some characteristics such as wide space, rapid spread, strong concealment and great harmfulness.Local debt risk is the focus of this paper.

\section{The Status Quo of China's Local Debt}

By the end of 2016, the balance of local government debt was expected to be 15300 billion yuan, down $4.3 \%$ from the end of 2015. Some local governments resolve a part of the existing debt through the co-ordination funds or PPP model transformation. Through a comprehensive analysis of the provincial government debt structure of China, we believe that the current trends are as follows:

\subsection{Net Investment Debt Declines}

Table 1. Basic data on City Investment bond in 2013-2015

\begin{tabular}{|c|c|c|c|}
\hline City Investment bond & 2013(million) & 2014(million) & 2015(million) \\
\hline Issue scale & 1044530 & 1908492 & 1760850 \\
\hline Repayment amount & 199892 & 416557 & 816423 \\
\hline Net financing & 844638 & 1491935 & 944427 \\
\hline proportion & $80.86 \%$ & $78.17 \%$ & $53.63 \%$ \\
\hline
\end{tabular}

From the Table 1, according to trends, the gradual increase in repayment pressure has squeezed the growth of net financing, net financing growth is significantly slower than the growth rate of the issue.

\subsection{The Proportion of Non-Rated Bonds Has Gradually Increased}

From the view of the city investment bonds' issued debt rating, because private debt issuance increased, so the proportion of non-rated bond is increase gradually, the amount of AAA class bonds also accounted for an increase. In 2013-2014, non-rated debt bond issuance ratio is relatively low, the province which the issue size accounted for more than $40 \%$ is relatively small (only Jilin, Henan and Guangxi provinces).But the proportion in the 2015-2016 increase, the number of 2015 is 15, and the number in 2016 has reached 17.In addition, in 2015 there are four provinces with non-rated bonds accounted for more than 50\% (Shanxi, Guangxi, Henan, Jiangsu), in 2016 this figure increased to 7.

\subsection{The Issuance Amount of Local Bonds Has Risen and Interest Rates Have Dropped}

In 2015, a total of 3835062 million yuan of local government debt was issued nationwide. Since 2016, the local government debt has been issued at 4567921 million yuan. As of August 2016, the scale of local debt issuance in 26 provinces has exceeded the annual data of 2015.Among them, Tianjin, Shanghai, Hunan and Guangdong region issued faster, Tianjin issued local debt reached more than 2 times, Shanghai and Hunan are also more than 1.5 times; Beijing, Jiangxi, Guizhou and Ningxia have a slower pace. In terms of interest rates of 2016, the weighted average issue rate has a significant decline, on average, a decline of about $40 \%$.

\subsection{Some of Typical Trends in Provinces and Municipalities}

Some of typical trends are listed as below:(1)The provinces rely on economic growth to resolve their debts.(2)The provinces rely on the transfer of land use rights, but it still faces great uncertainty. (3)Soil income has become a debt reduction tool, the real estate cycle is weak. The income from the transfer of the state-owned land use right is one of the important sources of revenue to resolve the debts ,but there is greater uncertainty about sustainability.(4)Debt replacement can ease the stock pressure, and PPP project can alleviate incremental pressure.

\section{The Risk Analysis of China's Local Debt}

When analyze the current situation of local debt, we find the following risk factors: 


\subsection{Lack of Consistency in Data and Standards}

The existing local debt information system in China lacks two core foundations: (1) lack of statistics and publication of relevant authoritative debt data; (2) lack of local government accounting standards for recognition and measurement of local debt; then lead to incomplete and opaque accounting and reporting of local debt.

\subsection{The Debt Risk Management System Is Imperfect}

At present, our country lacks the effective management system which can identify, analyze, prepare and deal with the debt risk. In particular, there is a lack of effective pre-warning mechanism and response tools for managing liquidity risks.

\subsection{The Debt Management Model Has Deficiencies}

Debt management model is not perfect, and the risk of management, control and responsibility is not clear. The allocation of power and responsibility between the central government and the local government, between local governments at all levels, between the government and the financing platform, and the state-owned enterprises under government control needs to be clear. The "risk egalitarianism" situation is still existed.

\subsection{The Separation of Local Debt Management and Budget Management}

The size of the debt that the local government issues is decided by the central government. Generally speaking, the amount may be known after the National People's congress. From the distribution of bond data to the completion of debt issuance, the process will be completed as early as May. Bringing existing local debt into budget management is not realistic. The object of budget management is the flow of income and expenditure, and the objective of debt management includes not only the capital flow, but also the stock debt or the debt balance. What can be included in the budget management is the increase in the balance of the debt and the interest paid in that year. Contingent liabilities cannot be included in the budget management.

\section{Measures for Establishing Pre-warning Mechanism of Local Debt Risk}

We can improve China's local government debt risk through the following countermeasures.

\subsection{Constructing Pre-warning Index System of Debt Risk}

The government should construct an pre-warning index system for local government debt risks suitable for China, select the corresponding indicators and determine the index weighting methods.

Now China is in the opening stage of the reform of local government independent authority to issue bonds gradually, local debt will gradually undergo structural adjustment. Because of reimbursement, replacement or restructuring, the city investment debt ratio will gradually reduce, local government debt ratio will increase, while accepting the debt ceiling limit. In this case, how to establish the pre-warning index system of the indicators design, and determine the index weight method combined with the development mode and Chinese economic background, is an important content to reduce the risk of local debt.

\subsection{Promote the Development of Fiscal Transparency}

The government and the professional organizations should actively promote the development of financial transparency and enhance the availability of basic data. The existing information disclose mode of local government finances by means of budget and final accounts, and most of them disclose only the budget information of the local government. If we want to establish a complete pre-warning model of local government debt risk, we need more economic data and debt data, which needs more transparent local financial system and information disclosure policy. With the local government allowing independent bonds, the responsibility of supervision and information disclosure can be further detailed and divided. The government should clear the main responsibility, and promote the development of fiscal transparency.

\subsection{Combine the Rating, Guarantees, Insurance and Risk Pre-warning of Local Debt}

The experience of western developed countries shows that the market is often a more effective means of balancing returns and risks. If there is a mature local debt rating or the insurance market, the assessment of the risk is not only the work of regulatory authorities, the relevant agencies or insurance institutions will provide more professional and effective risk measuring methods. At this 
point, the performance of local debt risk will often be shown earlier through market prices, changes in supply and demand, rating adjustment and so on.

\subsection{Improve the Financing System of Local Debt}

The financing system of local debt should be improved in two aspects. First, we should solve the central government's initiatives so as to clarify the obligations of local governments. Based on the division of administrative power between the central government and the local government, the division of expenditure responsibility and the design of the transfer payment system, the financing demand of the local debt has been determined. The other is the need to solve the accountability of provincial and municipal, county and township governments. The local government is not a general concept. Compared with the central government debt, local government debt is distributed at all levels, and so is the liability for repayment of debts.

\subsection{Establishment of a Comprehensive Financial Reporting System for Local Governments}

Comprehensive financial reporting system for local governments is the basis for assessing the risk of local government debt, improving governance, government standardization and financial transparency, and regulating debt management. The government should carry forward the reforming of the government accounting system, preparing and disclosing the local government balance sheet, then using the modern accrual accounting standard to prepare the government balance sheet, contains identification, measurement and reporting of government debt. Through the preparation and disclosure of the government balance sheet, the government can find out the "family property", the specific analysis of government assets and liabilities structure, proportion, period, reveals the government debt risk.

In addition, we can check how many assets of each local government can be realized, and how many assets can be realized through specific financial means (such as asset securitization). This will provide a practical understanding of the solvency of local governments.

\subsection{Setting Up Market Rating System of Local Debt}

Introducing the market rating system of local debt, the level of the local debt is evaluated by a professional rating firm, and the market forces are introduced to form external constraints. It important to establish local government bond rating and information disclosure system, and construct local debt monitoring index system, then gradually build an evaluation system of local government debt financing. We can achieve the aim by acts as below:(1) reflect the relevant indicators of local government capacity, such as the deficit rate or debt burden rate; (2) the indicators relevant to local government solvency, such as debt dependency, debt rate; (3) related indicators reflect the local debt structure, such as the term structure, maturity structure, and so on.

\subsection{Other Regulatory and Emergency Measures}

The government can try to establish a systematic framework and responsibility mechanism for debt risk management in order to mitigate fiscal risks. It is necessary to study the establishment of risk monitoring index system, such as debt ratio, new debt ratio, debt service ratio, interest payment rate, debt dependence, asset liability ratio, debt ratio, short-term debt ratio and secured debt ratio, etc.. In addition, we should speed up the establishment of the sinking fund system.

The government can also try to build an emergency response mechanism for local government debt risks, properly handle the existing debts and guard against debt risks by the use of large data information. When there is debt risk, the government can react and avoid quickly, or at least minimize the risk.

\section{Conclusion}

In recent years, the size and quantity of China's local debts have been changing constantly, and the risks also arise. In order to control the risk of local government debt, on the one hand, we need to expand investment and improve economic operation capacity to ensure the growth of debt achieve the established economic growth targets. Only economic sustainability can ensure fiscal sustainability. On the other hand, we need to constantly strengthen risk warning and management measures to control local debt risks by through the following measures, such as: constructing pre-warning index 
system of debt risk; promote the development of fiscal transparency; combine the rating, guarantees, insurance and risk pre-warning of local debt; improve the financing system of local debt; establishment of a comprehensive financial reporting system for local governments; set up market rating system of local debt, and other regulatory and emergency measures.

\section{Acknowledgments}

This work is financially supported by National Social Science Foundation Project of China: Research on local government debt accounting and pre-warning mechanism based risk management (No.14BGL045), Major Projects of Fujian Social Science Research base: Research on comprehensive financial earnings of government under Fiscal Decentralization (No.2014JDZ034) and Major Projects of Fujian Social Science Research base: Study on Fujian business spirit and enterprise accounting culture connotation (2016JDZ030).

\section{References}

[1] A Ang,J Bai,H Zhoul. The Great Wall of Debt: The Cross Section of Chinese Local Government Credit Spreads, Social Science Electronic Publishing, 2015:1-57.

[2] ZY Chen,H Mao,JX Zhang.Local Government Debt Maturity Mismatch:The Characteristics of Risk and Formation Mechanism, J.Economic Management Journal, 5(2015) :23-28.

[3] Yan Ming;Gu Wei-yu. Study on the Construction of Credit Risk Rating System of Local Government in China: the Framework and Methods,J. Journal of Central University of Finance \& Economics,3(2014): 15-21.

[4]Han Zenghua .Debt Risk Supervision and Performance Management: Observation of Local Government.J.Reform,6(2010):35-38

[5]X Miao.Status analysis and control measures of the debt risk in Chinese local government.J.China Finance \& Economic Review, 4(2016) :8-12 